COOPER, P. D. (1953). J. gen. Microbiol. 9, 199-206.

\title{
The Study of Cell Rupture in Staphylococcus aureus
}

\author{
BY P. D. COOPER \\ The Wright-Fleming Institute of Microbiology, St Mary's \\ Hospital Medical School, Paddington, W. 2
}

SUMMARY: In order to prepare staphylococcal cell walls as free as possible from intact organisms yet with minimum chemical and mechanical degradation, a rapid turbidimetric method was developed to measure the proportion of staphylococci ruptured by shaking with glass beads. The assay took less than a minute, and was used to find the bacterial concentration and speed and time of shaking which gave the biggest yields of cell walls in the shortest time.

When bacterial suspensions are shaken with small glass beads the turbidity decreases (Curran \& Evans, 1942) and the viable count steadily drops according to a logarithmic law (King \& Alexander, 1948). This appears to be due to mechanical rupture of the organisms, as the cell walls of the burst bacteria can be separated from the soluble cytoplasmic contents by centrifugation (Cooper, Rowley \& Dawson, 1949; Salton \& Horne, 1951). It has recently been found (Few, Cooper \& Rowley, 1952) that when penicillin-sensitive staphylococci are rapidly disrupted in a medium containing formalin ('Medium A', see below) the penicillin-binding component present in the organisms (Rowley, Cooper, Roberts \& Lester Smith, 1950) is retained in the cell wall, while rupture in distilled water alone gives inactive cell walls. In order to ascertain the optimum conditions for disruption, a rapid turbidimetric method was developed to estimate the number of bacteria disrupted. It had the advantage of enabling an on-the-spot estimation to be carried out in less than a minute. Thus at least $98 \%$ of the organisms could be broken without allowing the suspension to shake or stand more than necessary, so that mechanical and chemical degradation of the cell walls was minimized. The turbidimetric method and some factors affecting rate of rupture of staphylococci are described below.

\section{METHODS}

Preparation of bacterial suspensions. The organism used was a Cowan's type II penicillin-sensitive Staphylococcus aureus kindly supplied by Dr Hobbs of the Central Public Health Laboratory, Colindale. After growing on beef tryptic digest agar for $16 \mathrm{hr}$. at $37^{\circ}$ the organisms were harvested in distilled water, passed through a No. 1 porosity sintered glass filter funnel to remove agar particles, and washed 3 times with distilled water.

Apparatus used for bacterial disruption. A 'Microid' flask shaker (Messrs Griffin and Tatlock, London) oscillated a maximum load of four shaking tubes (each weighing $100 \mathrm{~g}$. with contents) at a continuously variable frequency of up to 45 cycles/sec., or two tubes up to 53 cycles/sec. The shaking tubes, $140 \mathrm{~mm} . \times 30 \mathrm{~mm}$. and with a row of indentations down each side to ensure 
turbulence while shaking, were closed by glass stoppers. The tubes contained $20 \mathrm{ml}$. bacterial suspension and $20 \mathrm{~g}$. glass 'Ballotini' beads (Messrs Chance Bros., Smethwick, England, 0.1-0.2 mm. diam., grade (12'). The tubes were clamped on the shaker in a horizontal position and shaken vertically with an amplitude of $2.5 \mathrm{~cm}$.

The shaking frequency was determined as follows. A bar magnet was clamped to the shaking arm close to the iron core of a solenoid of approximately 2000 coils which was connected to the $Y$ input of an oscilloscope. A calibrated oscillator connected to the $X$ input was set to a known frequency and the speed of the shaker was continuously tuned to this frequency during shaking by keeping the single Lissajou figure stationary. Without constant adjustment the frequency of the shaker was liable to vary by \pm 0.5 cycles/ sec. and a mains drop of 12 volts caused a frequency drop of 1 cycle/sec. The shaker ran at a different speed if not 'warmed up'. At what appeared to be the same adjustment the frequency differed from day to day. These variations were sufficient to prevent the reproducible rates of breakage necessary to find the optimum conditions, but were completely eliminated by using the tuning system described.

Assay of results. Bacterial dry wt. was determined with a Hilger absorptiometer calibrated in terms of mg. dry wt./ml.

The 'turbidity' of suspensions before and after shaking was measured on $0.25 \mathrm{ml}$. samples diluted to $10 \mathrm{ml}$. in distilled water contained in $1 \mathrm{~cm}$. cells in the same instrument with neutral filters. For the present purpose 'turbidity' is taken as the 'Spekker' dial reading, $=2-\log _{10}$ percentage transmission. The percentage of bacteria ruptured was calculated from the relation between the turbidities of a suspension before and after rupture. The relationship is derived below from the rate of drop in turbidity during rupture.

The number of viable organisms present in suspensions before and after shaking was determined by the method of Miles \& Misra (1938). Serial dilutions of the suspension were added to $5 \mathrm{ml}$. broth in capped bottles which were vigorously shaken before removal of the sample for the next dilution. Five drops of each broth dilution were allowed to fall on separate areas of an agar plate which was then tilted and rotated to spread the drops, and the colonies in each of the five groups formed were counted after $48 \mathrm{hr}$. incubation at $37^{\circ}$. Dilutions were arranged so that the number of colonies per group was 20-50.

The ratio of whole bacteria to cell walls was also observed directly from electron micrographs of washed suspensions.

Composition of shaking media. 'Medium A' contained in $100 \mathrm{ml} .: 1 \mathrm{ml}$. formalin solution, $0.5 \mathrm{~g}$. citric acid, $50 \mathrm{ml}$. distilled water saturated with octyl alcohol, 0.1 ml. mercaptoacetic acid (thioglycollic acid). These substances were added respectively to reduce enzyme activity, as buffer, to reduce enzyme activity (Meyerhof, 1949) and frothing, and to reduce possible autoxidation. 'Medium B' contained in $100 \mathrm{ml} .: 1 \mathrm{ml}$. formalin solution, $0.5 \mathrm{~g}$. citric acid. Both media were adjusted to $\mathrm{pH} 6.5$ with $10 \mathrm{~N}-\mathrm{NaOH}$ solution before final adjustment to volume with distilled water. 


\section{RESULTS}

\section{Changes of turbidity occurring during shaking}

The turbidity in distilled water was found to fall non-linearly with time of shaking and reached a nearly level value which was extrapolated to zero time to a value of about $17.5 \%$ of the initial turbidity in order to correct for the further slow drop in turbidity on continued shaking (Fig. 1). This value was

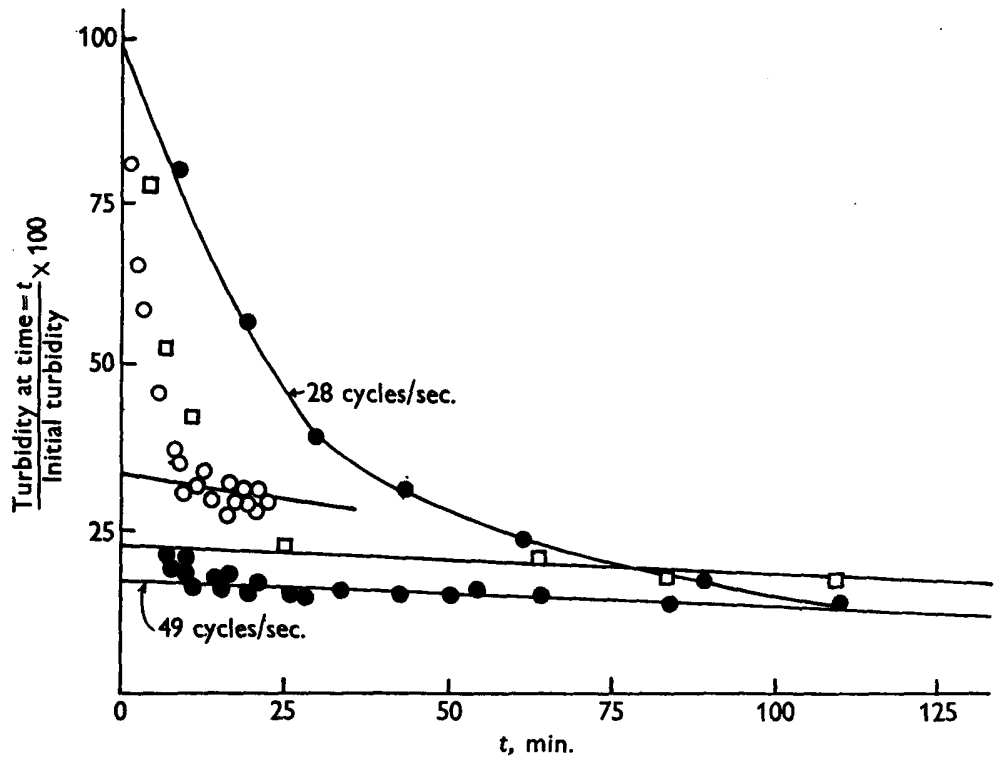

Fig. 1. Limiting turbidity reached on disrupting Staph. aureus at $2 \mathrm{mg}$. dry wt./ml. in distilled water, $\bigcirc-O, 28$ and 49 cycles/sec.; 'Medium B', $\square-\square, 49$ cycles/sec.; 'Medium A', O—O, 53.5 cycles/sec.

independent of the frequency of shaking and concentration of bacteria, although the rate at which it was approached depended on these factors.

In 'Medium A' and 'Medium B' the turbidity fell similarly to level values which were extrapolated to about 33 and $23.5 \%$ respectively of initial turbidity. At these levels electron micrographs, staining by Gram's method, and viable counts where applicable showed that substantially all the bacteria were disrupted. In all experiments the rate of turbidity decrease was less in the presence of formalin than in distilled water alone.

A plot against time of

$$
\log _{10}\left[\frac{\text { turbidity at time }=t}{\text { turbidity at time }=\text { zero }}-0 \cdot 175\right]
$$

gave a straight line for distilled water, and substitution of 0.175 by 0.235 for 'Medium B' and 0.33 for 'Medium A' also gave straight lines (Fig. 2). The values $0.175,0.235$ and 0.33 were chosen as those giving the best average extrapolations and straight lines for a large number of experiments, but from 
the range of deviations given in Fig. 2 for two lines it can be seen that they are liable to an error probably of the order of \pm 0.01 unit. The fact that the values giving the best straight lines corresponded closely with the best extrapolations supports the reasons for the choice of the formula

which are discussed below.

$$
\log \left[\frac{T_{t}}{T_{0}}-\text { constant }\right] \propto \text { time }
$$

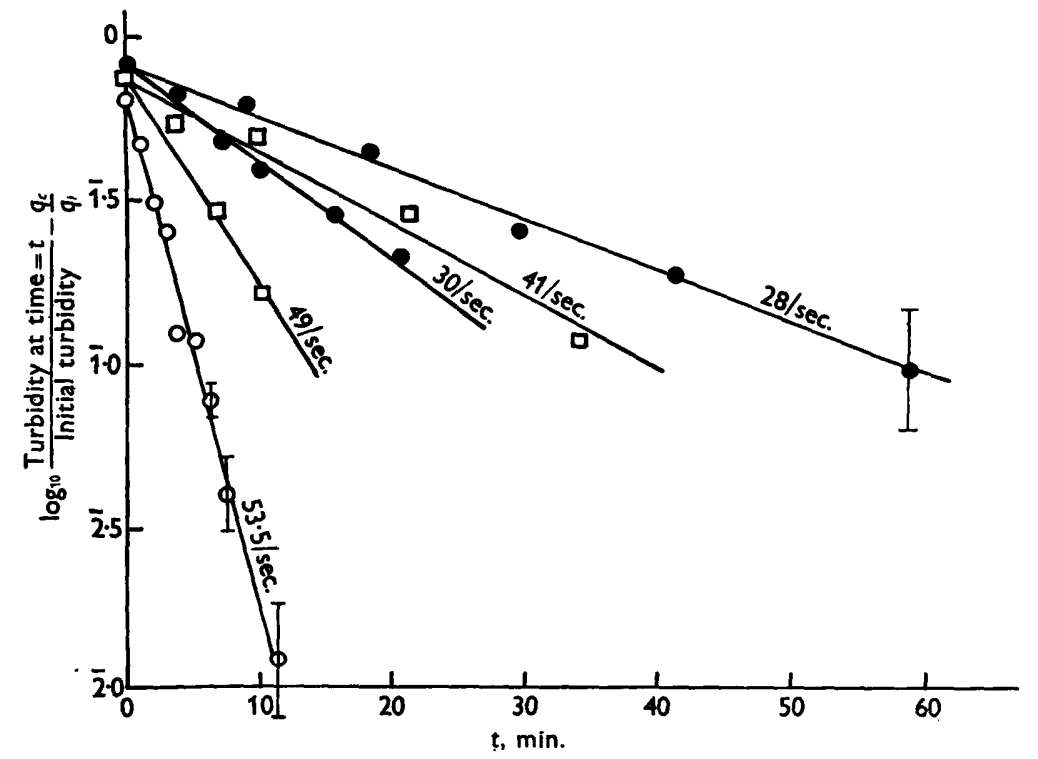

Fig. 2. Relation between $\log _{10}\left[\frac{\text { turbidity at time }=t}{\text { initial turbidity }}-\frac{q_{c}}{q_{i}}\right]$ and time of shaking where $\frac{q_{c}}{q_{i}}=0.175$, distilled water, $-0 ; 0.235$, 'Medium B', $\square-\square ; 0.33$, 'Medium A', $q_{i}$ - $\mathrm{O}$. The deviations shown on two curves represent variations caused by errors of \pm 0.01 unit in the values for $\frac{q_{e}}{q_{i}}$.

Correlation between the percentage of organisms ruptured calculated from turbidity measurements and that observed from viable and electron micrographic counts

It is demonstrated below that in distilled water the percentage of bacteria ruptured, $\boldsymbol{P}$, after $t$ minutes shaking should be given by the expression

$$
\frac{P}{100}\left[1-\frac{q_{c}}{q_{i}}\right]=1-\frac{Q}{q_{i}},
$$

where $q_{i}$ is the initial turbidity, $\frac{q_{c}}{q_{i}}=0.175$ and $Q$ is the observed turbidity at time $t$. Table 1 shows that the number of ruptured organisms calculated by this means from turbidity measurements agrees well with the number deduced from viable and electron micrographic counts. 
Table 1. Correlation between the rates of disruption calculated by means of turbidity measurements and observed from viable and electron micrograph counts. Experiments 1 and 2 performed on separate days but otherwise identical. $2 \mathrm{mg} . / \mathrm{ml}$. dry wt. of cells shaken in distilled water at $40 \mathrm{cycles} / \mathrm{sec}$.

\begin{tabular}{|c|c|c|}
\hline \multicolumn{3}{|c|}{ Experiment 1} \\
\hline & \multicolumn{2}{|c|}{$\%$ intact cells from } \\
\hline $\begin{array}{l}\text { Time } \\
\text { (min.) }\end{array}$ & $\begin{array}{l}\text { Viable } \\
\text { counts }\end{array}$ & $\begin{array}{l}\text { Turbidity } \\
\text { changes }\end{array}$ \\
\hline 0 & 100 & 100 \\
\hline 2 & $4,3 \cdot 3$ & $43 \cdot 2$ \\
\hline 4 & $16 \cdot 2$ & $16 \cdot 2$ \\
\hline 6 & $9 \cdot 6$ & $10 \cdot 2$ \\
\hline 8 & 4.7 & $4 \cdot 1$ \\
\hline 10 & $2 \cdot 6$ & 1.5 \\
\hline
\end{tabular}

\begin{tabular}{|c|c|c|}
\hline \multicolumn{3}{|c|}{ Experiment 2} \\
\hline & \multicolumn{2}{|c|}{$\%$ intact cells from } \\
\hline $\begin{array}{l}\text { Time } \\
\text { (min.) }\end{array}$ & $\begin{array}{l}\text { Electron } \\
\text { micrograph } \\
\text { counts }\end{array}$ & $\begin{array}{c}\text { Turbidity } \\
\text { changes }\end{array}$ \\
\hline o & 100 & 100 \\
\hline 1 & 82 & $81 \cdot 6$ \\
\hline 3 & $63 \cdot 1$ & $57 \cdot 4$ \\
\hline 5 & $45 \cdot 7$ & $39 \cdot 2$ \\
\hline 7 & $31 \cdot 4$ & $26 \cdot 4$ \\
\hline 9 & $24 \cdot 3$ & $19 \cdot 5$ \\
\hline 11 & $17 \cdot 4$ & 14.0 \\
\hline
\end{tabular}

Factors affecting rate of rupture

It can be seen from Fig. 2 that in presence of 'Medium B' the rate of rupture is considerably slowed. The rate of rupture is also dependent on frequency of oscillation, so that frequencies less than 30/sec. give a very slow break-up with the apparatus employed (Fig. 3). This rather critical value may be due to the

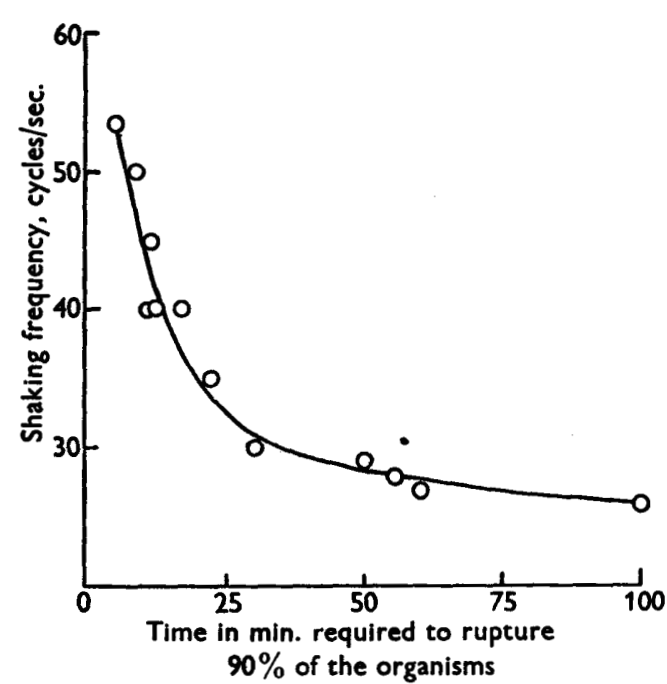

Fig. 8

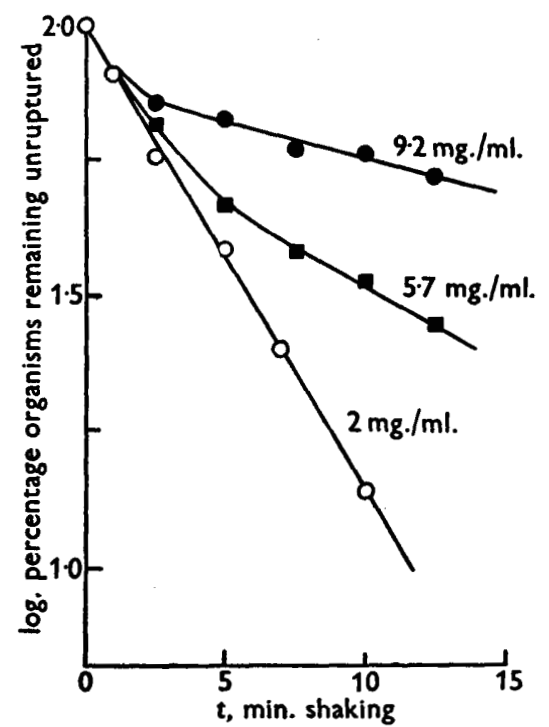

Fig. 4

Fig. 3. Relation between time required to rupture $90 \%$ of Staph. aureus calculated from turbidity measureménts, and frequency of shaking in distilled water at $2 \mathrm{mg}$. dry wt. of cells $/ \mathrm{ml}$.

Fig. 4. Effect of varying Staph. aureus concentration on rate of disruption in distilled water calculated from turbidity measurements. Shaken at 40 cycles/sec. $2 \mathrm{mg}$. dry wt. cells/ $\mathrm{ml} .$, O-O; $5 \cdot 7 \mathrm{mg} . / \mathrm{ml}$., $-\mathbf{n} ; 9 \cdot 2 \mathrm{mg} . / \mathrm{ml}$., 
use of vertical shaking, as little movement of the beads will occur unless the acceleration on the downward throw is greater than that due to gravity.

At bacterial concentrations greater than $2-3 \mathrm{mg} . / \mathrm{ml}$. the formation of cell walls ceases to follow a logarithmic law, and the rate of rupture falls off (Fig. 4), but below $2-3 \mathrm{mg} . / \mathrm{ml}$. the rate is independent of bacterial concentration. This slowing of rupture is probably due to frothing at the higher concentrations.

\section{DISCUSSION}

It can be shown experimentally that the sum of the 'turbidities' of suspensions of staphylococci at say $Y / \mathrm{ml}$. and staphylococcal cell walls at $Z / \mathrm{ml}$. is identical with the turbidity of a mixed suspension containing in $1 \mathrm{ml} . Y$ and $Z$ of the respective particles, and also that turbidity is directly proportional to concentration for both suspensions. Therefore the turbidity of a staphylococcal suspension after partial mechanical rupture with glass beads would be expected to consist of the sum of the turbidity due to unchanged cells and the turbidity of the cell walls produced from those bacteria which have been ruptured.

The rate of killing of bacteria by mechanical rupture follows a logarithmic law (King \& Alexander, 1948) so that, if complete rupture is the sole cause of killing, the turbidity of a given suspension after $t$ minutes shaking should equal

$$
q_{i} \cdot e^{-t / \lambda}+q_{c}\left[1-e^{-t / \lambda}\right]
$$

where $q_{i}=$ turbidity of the initial suspension, $q_{c}=$ turbidity of the cell walls produced by $100 \%$ rupture of that suspension, and $\lambda$ is a constant.

Thus $Q$, the observed turbidity at time $t$,

Therefore

$$
\begin{gathered}
=q_{i} \cdot e^{-t / \lambda}+q_{c}\left[1-e^{-t / \lambda}\right]=q_{c}+\left[q_{i}-q_{c}\right] \cdot e^{-t / \lambda} \\
\log \left[\frac{Q-q_{c}}{q_{i}}\right]=\log \left[\frac{q_{i}-q_{c}}{q_{i}}\right]-\frac{t}{\lambda}
\end{gathered}
$$

In this equation $Q$ and $t$ could be determined experimentally, $q_{i}$ was determined before the start of the experiment and $\frac{q_{c}}{q_{i}}$ should be given by the extrapolation of the level values of the turbidities finally reached, as in this case only cell walls were present.

Using these experimental values, a plot of $\log _{10}\left[\frac{Q}{q_{i}}-\frac{q_{c}}{q_{i}}\right]$ against time where $\frac{q_{c}}{q_{i}}$ was $0.175,0.235$ and 0.33 for distilled water, 'Medium B' and 'Medium A' respectively, was found to give a straight line. Thus it appeared that the changes in turbidity observed may closely follow the rate of rupture and killing of the organisms. This was confirmed by the close correlation found between the rate of fall of viable counts, rate of rupture observed from electron micrograph counts and the percentage of bacteria broken, $P$, which can be calculated from the relation

$$
Q=q_{i} \cdot \frac{(100-P)}{100}+q_{c} \cdot \frac{P}{100}, \quad \text { or } \quad \frac{P}{100}\left[1-\frac{q_{c}}{q_{i}}\right]=1-\frac{Q}{q_{i}} .
$$

In practice $P$ is obtained from the straight line graph relating $P$ to $\frac{Q}{q_{i}}$. 
As the rate of fall of viable counts has been found by other workers (King \& Alexander, 1948) to be logarithmic, it was assumed above that death only occurs simultaneously with complete rupture in order to deduce a logarithmic fall in turbidity. The fact that the observed results followed the theoretical equations and that viable and electron micrographic counts agreed closely with the production of cell walls calculated by this method confirm this assumption. Thus the staphylococci are able to withstand considerable agitation and only die when completely ruptured. It is not possible to say from this whether partially ruptured organisms are viable, or whether, as appears more likely, the mere splitting of the cell envelope kills the cell and the subsequent complete emptying of the cell contents to leave 'clean' cell walls occurs rapidly.

This correlation between rupture and killing differs from the recent findings of Furness (1952) with Bacterium coli, where the total count was always much higher than the viable count. This may possibly be due to the inclusion of partially ruptured organisms in the total count, as in my experience coliforms do not yield 'clean' cell walls on mechanical rupture in as high a proportion as do staphylococci.

The conditions for most rapid rupture obtained from the above data have been described elsewhere (Few et al. 1952).

The slow drop in the turbidity of cell wall suspensions on further shaking, which was more marked at higher speeds, seemed likely to be due to the mechanical disintegration of the cell walls which was noticed in electron micrographs of such suspensions. For this reason it was important not to shake longer or faster than necessary when preparing cell walls which were capable of binding penicillin, as the penicillin-binding component was easily removed by the mechanical grinding provided by the Ballotini beads. Formalin appears to protect the cells to some extent against rupture, and the cell walls prepared in 'Medium $\mathbf{A}$ ' contain more material and appear considerably thicker in electron micrographs than those from distilled water (Cooper, 1953).

A slight turbidity was observed when Ballotini beads were shaken alone in distilled water, due apparently to small splinters of glass. It did not interfere with the results described above, however, as it never amounted to more than $\frac{1}{2} \%$ of the turbidities measured, and also much less splintering occurred in the presence of the organisms than in their absence. The very small turbidity contributed by the ultramicroscopic 'lipid particles' of Mitchell \& Moyle (1951) also liberated on rupture of the organisms would be included in the term $q_{c}$.

I wish to express my thanks to London University for a grant for apparatus from the Central Research Fund, and to Dr C. Challice of the National Institute for Medical Research, Mill Hill, London, for electron micrographs. 


\section{REFERENCES}

Cooper, P. D. (1953). The site of action of penicillin. 2. The association of the penicillin-binding component (PBC) with a lipid fraction in Staphylococcus aureus. Biochem. J. (in the Press).

Cooper, P. D., Rowley, D. \& DAwson, I. M. (1949). Location of radioactive penicillin in Staphylococcus aureus after contact with the drug. Nature, Lond. $164,842$.

Curran, H. R. \& Evans, F. R. (1942). The killing of bacterial spores in fluids by agitation with small inert particles. J. Bact. 43, 125.

FEw, A. V., Cooper, P. D. \& Rowley, D. (1952). Reaction of penicillin with the staphylococcal cell wall. Nature, Lond. 169, 283.

FurNess, G. (1952). Some factors affecting the destruction of Bacterium coli by shaking with glass beads. J. gen. Microbiol. 7, 335.

KIng, K. H. \& AleXander, H. (1948). The mechanical destruction of bacteria. J. gen. Microbiol. 2, 815.

MeYerHoF, 0 . (1949). The Harden-Young effect in alcoholic fermentation of yeast preparations. J. biol. Chem. 180, 575.

Mires, A. A. \& Mrsra, S. S. (1938). The estimation of the bactericidal power of the blood. J. Hyg., Camb. 38, 732.

Mrtchell, P. \& MOYLE, J. (1951). Glycerophospho-protein complex envelope of Micrococcus pyogenes. J. gen. Microbiol. 5, 981.

Rowley, D., Cooper, P. D., Roberts, P. W. \& Lester Smith, E. (1950). The site of action of penicillin. I. Uptake of penicillin on bacteria. Biochem. J. 46, 157.

Salton, M. R. J. \& Horne, R. W. (1951). Studies on the bacterial cell wall. II. Methods of preparation and some properties of cell walls. Biochim. Biophys. Acta, 7, 177.

(Received 2 March 1953) 